\title{
Formulasi dan Karakteristik Bihun Tinggi Protein dan Kalsium dengan Penambahan Tepung Tulang Ikan Patin (Pangasius hypopthalmus) untuk Balita Stunting
}

\author{
Formulation and Characterization of Rice Noodles High Protein and \\ Calcium with Addition of Patin Fishbone Powder (Pangasius \\ hypopthalmus) for Children Under Five Years Stunting
}

\author{
Afrinis Nur*, Verawati Besti , Harahap Dewi Anggraini \\ Fakultas Ilmu Kesehatan, Universitas Pahlawan Tuanku Tambusai, \\ ( ${ }^{*}$ afrinis.eva@gmail.com)
}

\begin{abstract}
ABSTRAK
Masalah anak pendek (stunting) merupakan salah satu permasalahan gizi di Indonesia. Penyebab langsung stunting adalah penyakit infeksi dan asupan makanan yang tidak memadai, seperti kurang protein dan kalsium. Tulang ikan patin tinggi protein, kalsium dan fosfor yang dibutuhkan untuk pertumbuhan tulang balita. Salah satu cara pemanfaatan tulang ikan patin adalah diolah menjadi tepung dan dijadikan produk bihun untuk balita stunting. Tujuan penelitian ini adalah untuk mengetahui formula terbaik dan karakteristik bihun tinggi protein dan kalsium dengan penambahan tepung ikan patin (Pangasius hypopthalmus) untuk balita stunting. Rancangan penelitian menggunakan Rancangan Acak Lengkap. Variabel yang dikaji adalah nilai gizi tepung tulang ikan patin, yaitu analisis proksimat (kadar air, abu, protein, lemak, dan karbohidrat), analisis kalsium dan fosfor, dan uji organoleptik (uji hedonik dan mutu hedonik). Uji sensori dilakukan dengan metode rating hedonik dengan 25 panelis semi terlatih. Data dianalisis menggunakan ANOVA. Hasil penelitian menunjukkan, tepung tulang ikan patin memiliki kandungan gizi kadar air $6.79 \%$, kadar abu $64.23 \%$, kadar protein $20.39 \%$, lemak $3.36 \%$, karbohidrat $8.35 \%$, kalsium $1002.00 \mathrm{mg} / 100 \mathrm{~g}$ dan fosfor $12.80 \mathrm{mg} / 100 \mathrm{~g}$. Berdasarkan uji ANOVA terdapat pengaruh penambahan tepung tulang ikan patin terhadap rasa $(\mathrm{p}=0,001)$ dan aroma bihun $(\mathrm{p}=0,041)$, sedangkan dari segi warna $(\mathrm{p}=0.116)$, dan tekstur $(\mathrm{p}=0,102)$ tidak ada pengaruh penambahan tepung tulang ikan patin. Formulasi bihun terpilih adalah $\mathrm{F} 1$ (4\%) untuk anak balita stunting.
\end{abstract}

Kata kunci : Bihun, tulang ikan, tepung tulang ikan, stunting

\section{ABSTRACT}

Stunting is the nutritional problems in Indonesia. The direct cause of stunting was infectious disease and inadequate food intake such as protein and calcium deficiency. Patin fishbone powder contain high in protein, calcium and phosphor needed for growth children under five years. Utilization of patin fishbone powder is processed into flour and made rice noodle for children under five years stunting. The aims of the research were to determine the best formula and characteristics of rice noodles high protein and calcium with addition of patin fishbone powder (Pangasius hypopthalmus) for children under five years stunting. A complete randomized design was used for the experiment. Variables analyzed were : chemical properties (water content, total fat, total protein, carbohydrate by difference and ash content), calcium and phosphor, and sensory properties (hedonic test and hedonic quality). Hedonic test was conducted to determine the level of consumer acceptance of 25 semi-trained panelists. Data were analyzed by ANOVA. The results showed rice $n$ noodles with addition of patin fishbone powder (Hypopthalmus Pangasius) water content $6.79 \%$, ash $64.23 \%$, protein content $20.39 \%$, fat content $3.36 \%$, carbohydrate $8.35 \%$, calsium $1002.00 \mathrm{mg} / 100 \mathrm{~g}$ and fosfor $12.80 \mathrm{mg} / 100 \mathrm{~g}$. Based on ANOVA test there is the effect of addition of patin fishbone flour to taste $(p=0,001)$ and smell $(p=0,041)$, while color $(p=0.116)$ and texture $(p=0,102)$ have no effect. The best formula was rice noodles from $\mathrm{Fl}$ (4\%) for children under five years stunting.

Keywords : Rice noodles, patin fishbone, patin fishbone powder, stunting

Copyright $(\odot) 2018$ Universitas Hasanuddin. This is an open access article under the CC BY-NC-SA license

(https://creativecommons.org/licenses/by-nc-sa/4.0/).

DOI : http://dx.doi.org/10.30597/mkmi.v14i2.3984 


\section{PENDAHULUAN}

Bihun sudah dikenal oleh hampir seluruh rakyat Indonesia karena harganya yang ekonomis sehingga dapat dikonsumsi oleh masyarakat dari berbagai golongan ekonomi, mudah didapat, mudah diolah dan memiliki rasa yang enak dengan tekstur yang lembut setelah dimasak sehingga dapat dikonsumsi oleh semua golongan umur termasuk anak usia balita yang sudah makan makanan keluarga. Bihun merupakan bahan pangan sumber karbohidrat dan energi, tetapi rendah kalsium dan fosfor. ${ }^{1}$ Kalsium dan fosfor merupakan komponen penting dalam pertumbuhan tulang dan gigi. Selain terdapat dalam susu dan suplemen, kalsium dan fosfor dapat ditemukan didalam tulang ikan. Salah satu pangan lokal di Kabupaten Kampar adalah ikan patin.

Kabupaten Kampar merupakan penghasil ikan patin terbanyak di Provinsi Riau dalam satu hari dapat menghasilkan \pm 6 ton ikan patin. ${ }^{2}$ Salah satu desa di Kabupaten Kampar, yaitu Desa Koto Mesjid dikenal sebagai "Desa Kampung Patin" yang mendapat penghargaan Adibakti Mina Bahari Pembudidaya Teladan dan ditetapkan sebagai desa pengembangan terpadu. ${ }^{3}$ Usaha pengolahan ikan patin di Desa Koto Mesjid saat ini hanya mengolah bagian daging ikan patin menjadi nugget, abon, ikan asin, ikan salai dan kulit diolah menjadi kerupuk, sedangkan pengolahan tulang ikan masih belum optimal sehingga menjadi limbah. Usaha fillet ikan patin dilakukan empat kali dalam satu minggu dan menghasilkan limbah tulang ikan patin \pm 1.8 ton setiap pengolahan atau \pm 29 ton per bulan.

Tulang ikan memiliki proporsi $10 \%$ dari total seluruh tubuh ikan, tulang ikan merupakan salah satu limbah pengolahan ikan yang mengandung zat gizi mineral makro dan mikro. ${ }^{4}$ Mineral utama di dalam tulang adalah kalsium dan fosfor, sedangkan mineral lain dalam jumlah kecil adalah natrium, magnesium, dan flour. ${ }^{5}$ Tulang ikan patin dapat dimanfaatkan dengan diolah menjadi tepung sebagai bahan pangan sumber kalsium dan fosfor. Tepung tulang ikan patin adalah produk padat kering yang dihasilkan dengan cara mengeluarkan sebagian besar cairan yang terkandung di dalam tulang ikan patin. ${ }^{6}$

Tepung tulang ikan patin kaya akan zat gizi. Kandungan gizi tepung tulang ikan patin dapat diketahui dengan analisis proksimat dan analisis mineral. Analisis proksimat adalah penentuan persentase komponen-komponen utama (air, abu, lemak, protein dan karbohidrat) bahan pangan. ${ }^{7}$ Sedangkan analisis mineral adalah penentuan persentase kalsium dan fosfor bahan pangan. Tepung tulang ikan patin mengandung $25.6 \%$ kalsium dan $15.1 \%$ fosfor. ${ }^{8}$ Oleh karena itu, perlu dilakukan pengembangan produk makanan berupa bihun instan yang tinggi protein dan kalsium dengan inovasi pemanfaatan tepung tulang ikan patin dari limbah pembuatan tepung ikan patin sehingga diharapkan mampu memberikan kontribusi terhadap kecukupan asupan gizi khususnya protein dan kalsium pada balita stunting. Penelitian bertujuan mengetahui formula terbaik dan karakteristik bihun tinggi protein dan kalsium dengan penambahan tepung ikan patin (Hypopthalmus pangasius) untuk balita stunting.

\section{BAHAN DAN METODE}

Penelitian ini menggunakan desain eksperimental. Rancangan yang digunakan adalah Rancangan Acak Lengkap (RAL) non faktorial, hanya terdiri dari satu faktor, yaitu tepung tulang ikan patin dengan 3 kali pengulangan. Penelitian dilakukan di Laboratorium Kimia Pangan dan Hasil Perikanan Fakultas Perikanan dan Ilmu Kelautan Universitas Riau pada April- Agustus 2017.

Tulang ikan patin sebagai bahan utama yang digunakan dalam penelitian ini diperoleh dari usaha pengolahan ikan patin di desa Koto Mesjid. Bahan baku yang digunakan dalam pembuatan bihun instan adalah tepung beras dengan merk "Rose Brand", maizena dengan merk "Maizenaku", dan tepung tulang ikan patin. Sedangkan bahan tambahan bihun instan adalah air kansui yang terdiri dari campuran dari air dengan garam potasium karbonat, natrium karbonat, natrium tripolifosfat serta natrium klorida. Bahan kimia yang digunakan untuk analisis kandungan gizi yaitu aquades, $\mathrm{H}_{2} \mathrm{SO}_{4}$ pekat, selenium mix, $\mathrm{NaOH}$, pelarut Hexana, $\mathrm{HNO}_{3}$, $\mathrm{HCl}$, ammonium molibdat, potasium dihidrogen, etanol $95 \%$, metil merah, dan bahan kimia lainnya.

Alat yang digunakan dalam pembuatan bihun instan adalah timbangan analitik, sendok, alat gelas, loyang, mixer, ekstruder, steamer, dan cabinet dryer. Alat yang digunakan untuk analisis kimia adalah cawan alumunium, cawan porselin, 
Tabel 1. Formulasi Bihun Instan

\begin{tabular}{lcccc}
\hline \multirow{2}{*}{$\begin{array}{c}\text { Bahan pangan } \\
\text { (g) }\end{array}$} & F1 (4\%) & F2 (6\%) & F3 (8\%) & F4 (10\%) \\
\cline { 2 - 5 } & 70 & 70 & 70 & 70 \\
Tepung beras & 30 & 30 & 30 & 30 \\
Tepung maizena & 4 & 6 & 8 & 10 \\
Tepung tulang ikan patin & 80 & 80 & 80 & 80 \\
Air kansui & $\mathbf{1 8 4}$ & $\mathbf{1 8 6}$ & $\mathbf{1 8 8}$ & $\mathbf{1 9 0}$ \\
\hline \multicolumn{1}{c}{ Total } & & &
\end{tabular}

Keterangan:

$\mathrm{F} 1=$ penambahan tepung tulang ikan patin sebesar $4 \%$ dari berat tepung beras dan maizena

$\mathrm{F} 2=$ penambahan tepung tulang ikan patin sebesar $6 \%$ dari berat tepung beras dan maizena

$\mathrm{F} 3=$ penambahan tepung tulang ikan patin sebesar $8 \%$ dari berat tepung beras dan maizena

$\mathrm{F} 4=$ penambahan tepung tulang ikan patin sebesar $10 \%$ dari berat tepung beras dan maizena

oven, tanur, desikator, kondensor, soxhlet, labu kjehdahl, alat destilasi, labu enlenmayer, pompa vakum, labu takar, gelas ukur, Hotplate, botol gelas, uret, pipet, kertas saring, AAS (Atomic Absorption Spectrophotometer), spektrofotometer dan penjepit. Alat untuk analisis fisik, yaitu Chromameter dan Tensile Strength Tester. Uji organoleptik dan penerimaan bihun instan menggunakan kertas kuesioner, pulpen, piring bersekat, kotak makan dan kertas tissu.

Penelitian dilakukan dalam beberapa tahapan yaitu pembuatan tepung tulang ikan patin, uji proksimat, uji kalsium, uji fosfor, dan pembuatan bihun dengan beberapa kombinasi perlakuan. Bihun yang dijadikan sebagai kontrol yaitu bihun dengan bahan dasar $100 \%$ tepung terigu. Prosedur pembuatan tepung tulang ikan patin disesuaikan dengan metode Tabaka (2004), yaitu tulang ikan patin hasil fillet berupa tulang kepala, tulang tengah dicuci dengan air mengalir untuk membersihkan tulang ikan dari sisa sisa daging yang masih menempel. Tulang ikan tersebut kemudian dipotongpotong kecil dan dicuci kembali dengan air mengalir. Tulang ikan yang sudah bersih kemudian direbus dengan air mendidih $\left(100^{\circ} \mathrm{C}\right)$ selama 12 jam (4 jam per tahap perebusan). Tulang ikan patin yang sudah direbus kemudian dicuci kembali dengan air mengalir dengan tujuan memisahkan tulang dengan sisa daging. Tulang yang sudah bersih kemudian dijemur di bawah sinar matahari sampai tulang ikan kering. Tulang yang sudah kering digiling sampai halus dengan menggunakan blender dan diayak dengan ayakan 100 mesh. ${ }^{9}$

Analisis proksimat, kalisum dan fosfor tepung tulang ikan patin. Tepung tulang ikan patin dianalisis mutu gizinya meliputi kadar air (metode oven), kadar abu (metode gravimetri), kadar protein (metode kjeldahl), kadar lemak (metode soxhlet), karbohidrat (metode luff schoorl dan by different), kalsium (metode AAS), dan fosfor (metode spektrofotometri).

Pembuatan bihun substitusi tepung tulang ikan patin. Pembuatan bihun menggunakan tepung beras, tepung terigu, dan tepung tulang ikan patin dengan perbandingan 2:1:3 kemudian ditambahkan air $150 \mathrm{ml}$ yang kemudian dibentuk menjadi adonan pipih dan dicetak menjadi lembaran mi dengan menggunakan ampia. Setelah itu, bihun dikukus selama 5 menit lalu kemudian dijemur dibawah sinar matahari sampai bihun kering. Formulasi bihun instan dapat dilihat pada Tabel 1.

Uji sensori produk bihun instan dengan penambahan tepung tulang ikan patin dilakukan untuk pengukuran sifat fisik pangan seperti warna, rasa, aroma, bentuk, tekstur, kesukaan bihun terhadap tingkat penerimaan konsumen. ${ }^{10}$ Pengujian ini dilakukan oleh panelis agak terlatih sebanyak 25 orang. Dalam penelitian ini dilakukan uji hedonik dan mutu hedonik bihun dengan cara memberikan nilai berupa angka antara 1-5, dimana 1 (tidak suka), 2 (agak tidak suka), 3 (netral), 4 (agak suka), 5 (suka). ${ }^{11}$

Data hasil uji organoleptik dianalisis secara deskriptif menggunakan skor modus masingmasing perlakuan, kemudian dianalisis dengan menggunkan SPSS dengan uji one way ANOVA dengan tingkat kemaknaan 5\%. Apabila hasil ini menunjukkan adanya perbedaan diantara perlakuan maka dilakukan uji lanjut Duncan. 


\section{HASIL}

Tepung tulang ikan patin yang dihasilkan pada penelitian ini berwarna putih sedikit kecoklatan dengan tekstur yang sedikit kasar. Kandungan gizi tepung tulang ikan patin dapat dilihat pada (Tabel 2) yang menunjukkan bahwa kadar air yang diperoleh dari tulang ikan patin dengan metode kering adalah $6.79 \% \mathrm{bb}$. Kadar abu pada tepung tulang ikan patin adalah $64.23 \%$. Kadar lemak pada tepung tulang ikan patin yaitu $3.36 \%$ dan kadar karbohidrat pada tepung tulang ikan patin adalah $8.35 \%$. Kadar kalsium pada tepung tulang ikan patin, yaitu $1002.00 \mathrm{mg} / 100 \mathrm{~g}$ sedangkan fosfor yaitu $12.800 \mathrm{mg} / 100 \mathrm{~g}$.

Hasil uji hedonik bihun substitusi dapat dilihat pada Tabel 3 yang menunjukkan penerimaan rasa bihun untuk semua formula berkisar $60-80 \%$, yang berarti mayoritas panelis dapat menerima rasa bihun. Hasil uji hedonik terhadap rasa yang paling disukai panelis adalah bihun kontrol (F1), bihun F2 dan F3 dengan persentase 80\%. Hasil uji ANOVA menunjukkan bahwa terdapat perbedaan penambahan tepung tulang ikan patin terhadap rasa bihun (Tabel 5). Hal ini menujukkan bahwa semakin banyak penambahan tepung tulang ikan patin akan merubah rasa dari bihun. Hasil uji hedonik terhadap warna yang paling disukai panelis

Tabel 2. Kandungan Gizi Tepung Tulang Ikan Patin

\begin{tabular}{lc}
\hline \multicolumn{1}{c}{ Zat Gizi } & $\begin{array}{c}\text { Hasil } \\
\text { (\%) }\end{array}$ \\
\hline Analisis Proksimat & \\
Kadar Air & 6.79 \\
Kadar Abu & 64.23 \\
Protein & 20.39 \\
Lemak & 3.36 \\
Karbohidrat & 8.35 \\
Analisis Mineral & \\
Kalsium (mg/100g) & 1002.00 \\
Fosfor (mg/100g) & 12.8 \\
\hline
\end{tabular}

Tabel 4. Uji Mutu Hedonik

\begin{tabular}{lll}
\hline \multicolumn{1}{c}{ Formula } & $\sum$ & \% \\
\hline F0 $(0 \%)$ & 24 & 96 \\
F1 $(4 \%)$ & 21 & 84 \\
F2 $(6 \%)$ & 17 & 68 \\
F3 $(8 \%)$ & 19 & 76 \\
\hline
\end{tabular}

adalah bihun kontrol (F1) dan bihun F2 dengan persentase $100 \%$. Sedangkan tingkat kesukaan panelis terendah yaitu pada bihun F3. Warna yang dihasilkan dari 3 formulasi bihun jika dibandingkan dengan bihun kontrol tidak jauh berbeda dan hampir terlihat sama, yaitu berwarna putih bersih. Berdasarkan uji ANOVA menunjukkan tidak ada perbedaan penambahan tepung tulang ikan patin terhadap warna bihun.

Berdasarkan Tabel 3, hasil uji hedonik terhadap aroma bihun dengan penambahan tepung tulang ikan patin berkisar 70-90\% secara deskriptif berkisar agak suka sampai suka. Hasil uji ANOVA menunjukkan ada perbedaan penambahan tepung tulang ikan patin terhadap aroma bihun. Berdasarkan hasil uji hedonik penilaian panelis terhadap tekstur bihun berkisar antara 50-76\% jika dideskripsikan berkisar antara netral sampai agak suka. Tekstur bihun yang dihasilkan hampir sama di setiap perlakuan, yaitu sedikit lembut. Tingkat kesukaan tertinggi adalah bihun kontrol dengan persentase $76 \%$. Hasil uji ANOVA menunjukkan bahwa tidak ada perbedaan penambahan tepung tulang ikan patin terhadap tekstur bihun.

Hasil uji mutu hedonik dapat dilihat pada Tabel 4 yang menunjukkan secara keseluruhan bihun dengan penambahan tepung tulang ikan patin berkisar $76-96 \%$, jika dideskripsikan antara agak suka sampai suka. Berdasarkan Tabel 4, tingkat penilaian panelis tertinggi untuk mutu bihun formulasi adalah bihun F1 (bihun dengan penambahan tepung tulang ikan patin sebanyak 4\%) dengan persentase $84 \%$ dan bihun yang mendapat nilai terendah adalah bihun F2 (bihun dengan penambahan tepung tulang ikan patin sebanyak $6 \%$ ) dengan persentase penilaian panelis $68 \%$.

Hasil uji ANOVA penambahan tepung tulang ikan patin terhadap mutu bihun didapatkan hasil $\mathrm{p}<\alpha(0.002<0.05)$, hal ini menunjukkan bahwa terdapat perbedaan penambahan tepung tulang ikan patin terhadap mutu bihun. Berdasarkan uji lanjut Duncan penambahan tepung tulang ikan patin terhadap bihun tidak berbeda nyata. Hasil uji ANOVA penambahan tepung tulang ikan patin terhadap parameter rasa, warna, dan aroma bihun kontrol dan formulasi F1, F2, dan F3, dapat dilihat pada Tabel 5. Berdasarkan Uji ANOVA terdapat pengaruh penambahan tepung tulang ikan patin terhadap rasa $(\mathrm{p}=0,001)$ dan aroma bihun $(\mathrm{p}=0,041)$, 
Tabel 3. Hasil Uji Hedonik (Kesukaan)

\begin{tabular}{lcccccccc}
\hline \multirow{2}{*}{ Atribut Uji } & \multicolumn{8}{c}{ Formula } \\
\cline { 2 - 9 } & \multicolumn{2}{c}{ F1 (0\%) } & \multicolumn{2}{c}{ F2 (4\%) } & \multicolumn{2}{c}{ F3 (6\%) } & \multicolumn{2}{c}{ F4 (8\%) } \\
\cline { 2 - 9 } & $\sum$ & \% & $\sum$ & \% & $\sum$ & \% & $\sum$ & \% \\
\hline Rasa & 24 & 96 & 20 & 80 & 20 & 80 & 15 & 60 \\
Warna & 25 & 100 & 24 & 96 & 25 & 100 & 18 & 72 \\
Aroma & 23 & 92 & 23 & 92 & 18 & 72 & 20 & 80 \\
Tekstur & 19 & 76 & 17 & 68 & 14 & 56 & 15 & 60 \\
\hline
\end{tabular}

Tabel 5. Hasil Uji ANOVA Penambahan Tepung Tulang Ikan Patin terhadap Rasa, Warna, Aroma, dan Tekstur Bihun

\begin{tabular}{ccccc}
\hline Atribut & Mean & SD & F & Sig. \\
\hline Rasa Bihun & $3.12-4.44$ & $0.917-1.509$ & 6.232 & 0.001 \\
Warna Bihun & $3.72-4.16$ & $0.723-0.816$ & 1.730 & 0.166 \\
Aroma Bihun & $3.32-4.24$ & $0.970-1.249$ & 2.862 & 0.041 \\
Tekstur Bihun & $2.84-3.72$ & $1.179-1.308$ & 2.126 & 0.102 \\
\hline
\end{tabular}

sedangkan dari segi warna $(\mathrm{p}=0.116)$, dan tekstur $(\mathrm{p}=0,102)$ tidak ada pengaruh penambahan tepung tulang ikan patin. Hasil uji lanjut Duncan untuk atribut rasa dan aroma bihun tidak berbeda nyata. Berdasarkan uji organoleptik diperoleh bihun terpilih adalah bihun F1, yaitu bihun dengan penambahan tepung tulang ikan patin sebanyak $4 \%$. Dalam $78 \mathrm{~g}$ bihun dengan penambahan tepung tulang ikan patin $4 \%$ mengandung $230 \mathrm{kkal}$ energi, $6.5 \mathrm{~g}$ protein, $4.7 \mathrm{~g}$ lemak, $40.3 \mathrm{~g}$ karbohidrat, $82.1 \mathrm{mg}$ kalsium dan $90.3 \mathrm{mg}$ fosfor.

\section{PEMBAHASAN}

Hasil penelitian ini menghasilkan tepung tulang ikan patin dengan warna putih agak kecoklatan. Warna kecoklatan disebabkan oleh adanya reaksi non enzimatis selama pengeringan dengan menggunakan sinar matahari. Reaksi pencoklatan adalah reaksi antara protein khususnya gugus amina primer dengan karbohidrat terutama gula preduksi yang menghasilkan melanoidin yang berwarna coklat. ${ }^{5}$

Kadar air yang diperoleh dari tulang ikan patin dengan metode kering adalah $6.79 \% \mathrm{bb}$. Hal ini dikarenakan proses pengeringan dalam pembuatan tepung tulang ikan menggunakan metode pengeringan tradisional dengan bantuan sinar matahari yang memiliki kelemahan yaitu suhu dan kelembaban sulit dikontrol dan waktu yang diperlukan untuk pengeringan bahan pangan tidak dapat ditentukan.

Hasil kadar protein pada tulang ikan patin dengan menggunakan metode semi mikro kjedahl adalah $20.9 \%$. Metode yang digunakan pada penelitian ini perebusan dilakukan sebanyak tiga kali pengulangan dengan waktu 4 jam setiap kali perebusan sehingga pada penelitian ini lama perebusan tulang ikan adalah 12 jam. Proses pemasakan berulang akan memecah kolagen sehingga lebih mudah terbawa oleh air. Saat kolagen menjadi gelatin, sifat kolagen tidak bewarna, tidak berasa dan larut dalam air panas, sehingga banyak kolagen yang larut dalam air dan terbuang pada saat pembersihan. Jadi, semakin lama waktu pengolahan dengan suhu tinggi akan menyebabkan kandungan protein yang dihasilkan akan semakin rendah.

Hasil analisis kadar lemak pada tepung tulang ikan patin dengan menggunakan metode ekstraksi Soxhlet yaitu 3.36\%. Beberapa proses yang mempengaruhi kadar lemak adalah proses pembersihan sisa-sisa daging dari tulang ikan. Selain itu, perebusan dapat menyebabkan lemak mengalami hidrolisis atau auto oksidasi sebagian. Produk dengan kadar lemak yang rendah mempunyai daya awet yang lebih lama.

Berdasarkan hasil analisis kadar karbohidrat pada tepung tulang ikan patin adalah $8.35 \%$. Penelitian ini menggunakan metode Luff-Schrool dimana kadar karbohidrat yang dihasilkan tidak termasuk serat kasar. Karbohidrat merupakan 
sumber utama kalori atau energi bagi manusia. Karbohidrat juga mempunyai peran penting dalam menentukan karakteristik bahan makanan seperti rasa, warna, aroma, dan tekstur makanan. ${ }^{5}$ Karbohidrat memberikan rasa manis pada makanan, memberikan aroma dan bentuk yang khas pada makanan serta memberi warna dan pelembut tekstur makanan.

Berdasarkan analisis kalsium pada tepung tulang ikan patin yaitu $1002.00 \mathrm{mg} / 100 \mathrm{~g}$. Tepung tulang ikan patin yang tinggi kalsium adalah tepung tulang ikan yang sudah diolah dan bebas dari cemaran biologis dan kimia. Kalsium berfungsi untuk pembentukan tulang dan gigi, mengatur kontraksi otot termasuk denyut jantung, proses pembekuan darah dan sebagai katalis reaksi biologis. Kekurangan kalsium dapat menyebabkan terjadinya metabolisme tidak normal

Berdasarkan hasil analisis fosfor yaitu $12.800 \mathrm{mg} / 100 \mathrm{~g}$. Pada penelitian ini alat yang digunakan adalah spektofotometri dengan panjang gelombang $660 \mathrm{~nm}$. Fosfor merupakan komponen dari tulang ikan. Fosfor merupakan mineral terbanyak setelah kalsium. Peranan fosfor hampir sama dengan kalsium yaitu untuk pembentukan tulang dan gigi. ${ }^{5}$ Fosfor banyak dijumpai hampir pada semua jenis makanan terutama didalam daging merah, susu, ikan, unggas, roti, beras, dan gandum. Sumber fosfor yang utama adalah bahan makanan dengan kadar protein tinggi. Bahan pangan yang tinggi protein dan kalsium biasanya juga tinggi fosfor. ${ }^{5}$

Berdasarkan rasa bihun, mayoritas panelis dapat menerima rasa bihun berkisar $60-80 \%$. Hasil penelitian menunjukkan bahwa terdapat perbedaan penambahan tepung tulang ikan patin terhadap rasa bihun. Hal ini menujukkan bahwa semakin banyak penambahan tepung tulang ikan patin akan merubah rasa dari bihun. Hal ini dikarenakan semakin banyak penambahan tepung tulang ikan rasa bihun terasa sedikit berkapur karena kandungan kalsium dan fosfor yang tinggi pada tepung tulang ikan patin. Sehingga semakin tinggi formulasi tepung tulang ikan patin menyebabkan penilaian terhadap rasa semakin menurun. Penelitian ini sejalan dengan penelitian Mulia, yaitu semakin banyak penambahan tepung tulang ikan patin mempengaruhi mutu mie yang dihasilkan dari segi rasa. Semakin banyak penambahan tepung tulang ikan patin menyebabkan rasa menurun. Hal ini dikarenakan kandungan abu atau mineral kalsium yang tinggi pada tepung tulang ikan patin membuat rasa pada produk yang dihasilkan seperti berkapur atau sedikit terasa berpasir. ${ }^{8}$

Berdasarkan warna bihun sebanyak 70$100 \%$ agak suka. Hal ini menunjukkan warna bihun dapat diterima oleh panelis. Warna yang dihasilkan dari 3 formulasi bihun jika dibandingkan dengan bihun kontrol tidak jauh berbeda dan hampir terlihat sama yaitu berwarna putih bersih. Berdasarkan uji ANOVA menunjukkan tidak ada perbedaan penambahan tepung tulang ikan patin terhadap warna bihun. Penelitian ini sejalan dengan penelitian Kaya, yaitu penambahan tepung tulang ikan patin tidak memberikan perbedaan penilaian panelis terhadap warna biskuit yang dihasilkan.

Berdasarkan aroma bihun dengan penambahan tepung tulang ikan patin berkisar $70-90 \%$ secara deskriptif berkisar agak suka sampai suka. Tingkat kesukaan tertinggi terhadap aroma bihun terdapat pada bihun kontrol dan pada bihun dengan penambahan tepung tulang ikan patin $4 \%$, yaitu $92 \%$ dan tingkat kesukaan terkecil terdapat pada bihun dengan penambahan tepung tulang ikan patin $6 \%$ yaitu $72 \%$. Dalam pembuatan bihun tepung beras lebih dominan sehingga aroma tepung tulang ikan tidak terlalu tercium sehingga aroma bihun dengan campuran tepung tulang ikan patin lebih disukai oleh panelis, jika dibandingkan dengan bihun kontrol atau tanpa penambahan tepung tulang ikan patin. Hasil uji ANOVA menunjukkan ada perbedaan penambahan tepung tulang ikan patin terhadap aroma bihun. Penelitian ini sejalan dengan penelitian Tabaka, yaitu penambahan tepung tulang ikan patin memberikan perbedaan tingkat kesukaan panelis terhadap aroma kerupuk yang dihasilkan. ${ }^{9}$

Penilaian panelis terhadap tekstur bihun berkisar antara 50-76\% jika dideskripsikan berkisar antara netral sampai agak suka. Tekstur bihun yang dihasilkan hampir sama di setiap perlakuan, yaitu sedikit lembut. Hasil uji ANOVA menunjukkan bahwa tidak ada perbedaan penambahan tepung tulang ikan patin terhadap tekstur. Hal ini sejalan dengan penelitian Tabaka, yaitu penambahan tepung tulang ikan patin tidak memberikan perbedaan tingkat penilaian panelis terhadap tekstur kerupuk yang dihasilkan sehingga tingkat 
kesukaan panelis terhadap tekstur kerupuk hampir sama untuk semua produk kerupuk yang dihasilkan. ${ }^{9}$

Nilai gizi bihun terpilih mampu memenuhi kebutuhan gizi anak usia 12-24 bulan untuk porsi makan siang. Proporsi kebutuhan anak usia 12-24 bulan untuk makan siang yaitu sebanyak $30 \%$ dari kebutuhan energi total dalam sehari. Anak umur 12-24 bulan kebutuhan zat gizi semakin meningkat dan tidak lagi dapat dipenuhi hanya dari ASI. Untuk mencapai gizi seimbang perlu ditambah dengan MP-ASI, dan ASI tetap diberikan sampai anak berusia 24 bulan. Saat anak sudah berusia 12 bulan sudah dapat diberikan makanan keluarga. MP-ASI diperlukan karena pada usia 12-24 bulan ASI hanya menyediakan $1 / 3$ dari kebutuhan gizi. ${ }^{12}$

Bihun formula terpilih dapat dijadikan sebagai makanan MP-ASI untuk makan siang pada anak usia 12-24 bulan dengan penambahan tepung tulang ikan patin $4 \%$ mengandung zat gizi $230 \mathrm{kkal}$ energi, $6.5 \mathrm{~g}$ protein, $4.7 \mathrm{~g}$ lemak, $40.3 \mathrm{~g}$ karbohidrat, $82.1 \mathrm{mg}$ kalsium dan $90.3 \mathrm{mg}$ fosfor. Sedangkan kebutuhan yang harus dipenuhi MPASI berdasarkan AKG adalah 225 kkal energi, $5.2 \mathrm{~g}$ protein, $8.8 \mathrm{~g}$ lemak, $31 \mathrm{~g}$ karbohidrat, 130 $\mathrm{mg}$ kalsium, dan $100 \mathrm{mg}$ fosfor.

Sup bihun yang dihasilkan tidak hanya tinggi zat gizi makro tetapi juga tinggi zat gizi mikro yaitu kalsium dan forsfor. Kebutuhan kalsium yang harus dipenuhi dari MP-ASI adalah $130 \mathrm{mg}$, sedangkan kalsium yang ada pada sup bihun hanya $82.1 \mathrm{mg}$ tetap dikatakan tinggi kalsium karena kadar kalsium pada sup bihun sudah memenuhi $20 \%$ AKG, yaitu $20 \%$ dari $130 \mathrm{mg}$ adalah $26 \mathrm{mg}$. sedangkan kadar fosfor yang harus dipenuhi dari MP-ASI, yaitu $100 \mathrm{mg}$ dan kadar fosfor pada sup bihun sudah memenuhi, yaitu $90.3 \mathrm{mg}$. Berdasarkan hal tersebut dapat disimpulkan sup bihun sudah dapat memenuhi kebutuhan gizi anak usia 1224 bulan untuk makan siang.

\section{KESIMPULAN DAN SARAN}

Tepung tulang ikan patin yang dihasilkan pada penelitian ini berwarna putih sedikit kecoklatan dengan tekstur yang sedikit kasar. Kandungan gizi tepung tulang ikan patin dianalisis dengan menggunakan analisis proksimat dan mineral. tepung tulang ikan patin Hasil analisis proksimat dan mineral. Kandungan gizi tepung tulang ikan patin sebagai berikut: kadar air $6.79 \%$, kadar abu $64.23 \%$, protein $20.39 \%$, karbohidrat $8.35 \%$ dan mineral kalsium $1002.00 \mathrm{mg} / 100 \mathrm{~g}$ serta fosfor $12.8 \mathrm{mg} / 100$. Berdasarkan uji ANOVA terdapat pengaruh penambahan tepung tulang ikan patin terhadap rasa dan aroma bihun, sedangkan dari segi warna dan tekstur tidak ada pengaruh penambahan tepung tulang ikan patin. Adapun formula terpilih adalah formula F1 yaitu bihun dengan penambahan tepung tulang ikan patin sebanyak $4 \%$.

Saran untuk penelitian selanjutnya yakni dilakukannya intervensi berupa pemberian bihun instan dengan penambahan tepung tulang ikan patin sebanyak 4\% untuk balita stunting. Sup bihun sudah dapat memenuhi kebutuhan gizi anak usia 12-24 bulan untuk makan siang.

\section{UCAPAN TERIMAKASIH}

Penulis mengucapkan terima kasih dan penghargaan kepada Ditjen Dikti yag telah memberikan dana penelitian, dan Dinas Kesehatan Kabupaten Kampar yang telah mengizinkan penelitian sehingga bisa memberikan manfaat untuk semua pihak.

\section{DAFTAR PUSTAKA}

1. Astawan M. Panduan Karbohidrat Terlengkap. Jakarta (ID): Dian Rakyat; 2009.

2. Dinas Perikanan dan Kelautan Provinsi Riau. Pekanbaru : Buku Tahunan Statistik Perikanan Provinsi Riau. Pekanbaru; 2013.

3. Yantos. Kajian Pemerintah Kabupaten Kampar terhadap Peningkatan Daya Saing UKMK Desa Koto Mesjid dalam Menghadapi Masyarakat Ekonomi ASEAN (MEA). Jurnal RISALAH. 2016;27(1):32-4.

4. Kaya A O W. Pemanfaatan Tepung Tulang Ikan Patin (Pangasius SP) sebagai Sumber Kalsium dan Fosfor dalam Pembuatan Biskuit [Skripsi]. Bogor (ID): Institut Pertanian Bogor; 2008.

5. Winarno FG. Kimia Pangan dan Gizi. Jakarta (ID): PT Gramedia Pustaka; 2008.

6. Lestari S. Pemanfaatan Tulang Ikan Tuna (Limbah) untuk Pembuatan Tepung Tulang [Skripsi]. Bogor (ID): Institut Pertanian Bogor; 2001.

7. Santoso J, Gunji S, Yoshie SY, Suzuky T. 
Mineral Content of Indonesian Seaweeds and Mineral Solubilityaffecsted by Basic Cooking. Food Sci.Tech. Res. 2012;12:59-66.

8. Mulia. Kajian Potensi Limbah Tulang Ikan Patin (Pangasius SP) sebagai Alternatif Sumber Kalsium dalam Produk Mi Kering [Skripsi]. Bogor (ID): Institut Pertanian Bogor; 2004.

9. Tabaka R. Pemanfaatan Tepung Tulang Ikan Patin (Pangasius SP) dalam Pembuatan Mi Kering [Skripsi]. Bogor (ID): Institut Pertani- an Bogor; 2004.

10. Syah D. Pengantar Teknologi Pangan. Bogor (ID): IPB Press; 2012.

11. Setyaningsih D, Aprianto A, Sari MP. Analisis Sensori untuk Industri Pangan dan Argo. Bogor (ID): IPB Press; 2010.

12. Kemenkes RI. Hasil Riset Kesehatan Dasar 2013. Jakarta: Badan Penelitian dan Pengembangan Kesehatan; 2013. 